\title{
Exploring Potential Effects of Cormorant Predation on the Fish Community in Saginaw
}

\section{Bay, Lake Huron}

Robin L. DeBruyne, ${ }^{\mathrm{a}, \mathrm{b}, *}$, David G. Fielder ${ }^{\mathrm{c}}$, Edward F. Roseman $^{\mathrm{d},}$ and Peter H. Butchko ${ }^{\mathrm{e}, 1}$

${ }^{\mathrm{a} U . S . ~ G e o l o g i c a l ~ S u r v e y, ~ G r e a t ~ L a k e s ~ S c i e n c e ~ C e n t e r, ~} 1451$ Green Rd, Ann Arbor, MI 48105,

USA

${ }^{\mathrm{b}}$ Department of Environmental Sciences, University of Toledo, 2801 W. Bancroft, Toledo, OH, 43606, USA

${ }^{\mathrm{c}}$ Michigan Department of Natural Resources, Alpena Fisheries Research Station, 160 E. Fletcher, Alpena, MI 49707, USA

${ }^{\mathrm{d}}$ U.S. Department of Agriculture, Animal and Plant Health Inspection Service, Wildlife Services, 2803 Jolly Rd, Okemos, MI 48864, USA

* Corresponding Author: Telephone: 734-994-3331 x228; Fax: 734-994-8780; e-mail: rdebruyne@usgs.gov

${ }^{1}$ Retired 


\begin{abstract}
Stakeholders and fishery managers expressed concern that double-crested cormorant

Phalacrocorax auritus predation may be a factor in the recent poor survival of yellow perch Perca flavescens in Saginaw Bay. We quantified cormorant diets from two nesting colonies in Saginaw Bay during April-September in 2013 and 2014, with special emphasis on impacts to yellow perch. Cormorants $(n=691)$ were collected when returning to colonies after foraging. Stomachs were removed and preserved in the field. Diet items were identified, enumerated, and measured $(n=23,373)$. Cormorant diets from Saginaw Bay indicate a heavy reliance on round goby and Notropis species as prey during the breeding season, consistent with other areas of the Great Lakes where round goby and cormorants coincide. Respectively, the three most common prey species observed by number (\%) and biomass (\%) pooled across years and sites were round goby Neogobius melanostomus $(56.6 \%, 42.1 \%)$, emerald shiner Notropis antherinoides (25.2\%, $12.5 \%)$, and yellow perch $(8.0 \%, 14.1 \%)$. Diet composition was more variable at Spoils Island than at Little Charity Island. Overall cormorant consumption (estimated using cormorant consumption demand rates) of yellow perch was compared to walleye consumption. Cormorant consumption of age-1 yellow perch was $13-17 \%$ as much as mean walleye consumption of yellow perch in 2013 and $8-11 \%$ in 2014 . The cumulative effects of walleye and spring cormorant predation likely represent a recruitment bottleneck for yellow perch in Saginaw Bay. Future studies determining age-specific abundance of yellow perch would facilitate better determination of cormorant predation significance.
\end{abstract}

Keywords: diet; double-crested cormorant; round goby; Saginaw Bay; walleye; yellow perch 


\section{Introduction}

Double-crested cormorants (Phalacrocorax auritus, hereafter referred to as cormorants) have proliferated in the Great Lakes region since the early 1990s (Wires and Cuthbert, 2006; Ridgway and Fielder, 2012). Their dramatic recovery and exponential rise in abundance is attributed to a suite of factors including the 1972 ban on DDT, protection under the Federal Migratory Bird Treaty Act, increased availability of forage fish in the Great Lakes, most notably the exotic alewife Alosa pseudoharengus, development of intensive aquaculture in the southern United States, and lastly, the creation of additional breeding and foraging habitat in the form of reservoirs and dredge spoils islands (Wires and Cuthbert, 2006). In Lake Huron, for example, cormorants increased from near zero in 1980 to over 30,000 nesting pairs by 2005 (Ridgway and Fielder, 2012). Because cormorants are piscivorous, their increasing numbers concern anglers and natural resource professionals in the Great Lakes region (United States Fish and Wildlife Service [USFWS], 2003).

Saginaw Bay (Fig. 1) is a large $\left(2,947 \mathrm{~km}^{2}\right)$ shallow bay in the Michigan waters of Lake Huron that ranges from an average depth of approximately $4.6 \mathrm{~m}$ in the inner bay to $14.6 \mathrm{~m}$ in the outer bay. Saginaw Bay has a number of islands, with Little Charity and Spoils islands used by nesting cormorants. As with much of the Great Lakes, the number of cormorants inhabiting the islands in Saginaw Bay has grown considerably since the 1980s. Nest counts on Little Charity Island (the larger of the two cormorant colonies) peaked in 2010 at 2,715 nesting pairs (E. Dunton, USFWS, personal communication). Cormorants have been found to dive up to $25 \mathrm{~m}$ in the Great Lakes (Coleman, 2009), and therefore can feed at all depths in Saginaw Bay. Cormorants are usually regarded as opportunistic feeders (Lewis, 1929; Ludwig et al., 1989; Neuman et al., 1997) and typically consume prey smaller than those targeted by anglers (VanDeValk et al., 2002; Barks et al., 2010; Ridgway et al., 2012), but have been found to select 
specific prey species when available in some systems (DeBruyne et al., 2013; Schultz et al., 2013). Applying the adult consumption rate of Ridgway (2010) to the bioenergetics model for adult cormorants and fledgling consumption rates for successful nests found in Seefelt and Gillingham (2008), and allowing one sexually immature non-breeder for every pair of adult birds, it is estimated that the cormorant colony on Little Charity Island consumed 662,000 kilograms of fish in 2010.

There were three distinct periods for the yellow perch (Perca flavescens) population in Saginaw Bay. In the 1980s until about 1994, yellow perch were abundant, but small, due to slow growth (Salz, 1989; Haas and Schaeffer, 1992; Schaeffer et al., 2000). Yellow perch production (age-0) declined with the dreissenid mussel colonization beginning in 1993, which was followed by reduced adult yellow perch abundance and harvest in the recreational and commercial fisheries (Fielder and Thomas, 2006). Since 2003, Lake Huron has undergone additional profound food web changes driven primarily by the extirpation of alewife from most of the lake, including Saginaw Bay (Riley et al., 2008; Roseman and Riley, 2009). In the absence of alewife, yellow perch reproductive success in Saginaw Bay has increased dramatically (increased fall age- 0 bottom trawl catch), however recruitment to age- 1 and older (in fall) is still severely limited (Figure 2; Fielder and Thomas, 2014; Fielder et al., 2014). The lack of older yellow perch has resulted from very high mortality rates of young yellow perch, attributed to increased predation from walleye (Sander vitreus) and possibly overwinter mortality (Ivan et al., 2011; Fielder and Thomas, 2014). Cormorants also consume young yellow perch (Burnett et al., 2002; Rudstam et al., 2004; DeBruyne et al., 2013) and alewife (Newman et al., 1997; Diana et al., 2006; DeBruyne et al., 2012), thus the need to describe their overall diet in light of the food web changes served as the primary impetus for this diet study. 
Cormorants were implicated in the decline of sportfish populations in some areas of the Great Lakes region (Burnett et al., 2002; Lantry et al., 2002; Rudstam et al., 2004; Fielder, 2008; Dorr et al., 2010). Cormorant diets, however, have been shown to be diverse, and sport species may not be the principle species consumed (Craven and Lev, 1987; Diana et al., 2006; Johnson et al., 2010, 2015b; DeBruyne et al., 2012, 2013). This complexity in diet complicates interpretation of predation significance on sportfish populations. Therefore, investigations of the role that cormorants occupy in food webs can provide important information for managers when they are assessing the potential need to manage cormorants to protect fisheries resources. Ideally, these studies should be done in areas where comparable fisheries data or other predator diet information is available to help frame the range of potential impacts. Our objectives in this study were to: (1) quantify and characterize the monthly diet composition of cormorants in Saginaw Bay during 2013 and 2014, (2) estimate the total consumption of yellow perch by cormorants for each year examined, and lastly, (3) compare the magnitude of cormorant predation on yellow perch to that of walleye, which is regarded as being the single most abundant predator in Saginaw Bay.

\section{Methods}

Cormorants were collected from two areas in Saginaw Bay, near Little Charity Island (outer Saginaw Bay) and Spoils Island (inner bay near the Saginaw River mouth) (Fig. 1). Collections were made by USDA Animal and Plant Health Inspection Service, Wildlife Services using shotguns when birds returned to the nesting colonies to increase the probability of full stomachs. Approximately 25 birds were collected monthly at each nesting colony from 26 April - 16 September (2013) and from 06 May - 19 September (2014); expanded sampling was conducted in May and August 2014 (Table 1) to better describe temporal variability during 
spring and fall. Stomachs were removed, placed in bags with identification tags, and frozen until laboratory processing. In the laboratory, stomachs were thawed and diet items were identified to the lowest possible taxon. Partially digested prey were identified using cleithra when necessary (Traynor et al., 2010). All prey items were enumerated and total, standard, or backbone length measurements were taken and used to estimate weight from published species-specific lengthweight regressions (Carlander and Smith, 1945; Beckman, 1948; Knight et al., 1984; Hartman and Margraf, 1992; Elliot et al., 1996; Schneider et al., 2000; Johnson et al., 2005; Truemper and Lauer, 2005; Fielder and Thomas, 2006). For prey items that were too digested to obtain a length, lengths were estimated from either mean length from the same species in the same cormorant stomach (preferred method), or the mean length for that species from the same colony and month. Cormorant diet composition was characterized by month and site using percent by number and percent by weight of prey species for all consumed prey in Saginaw Bay.

Yellow perch mean total lengths by age $( \pm 2 \mathrm{SD})$ from annual fisheries surveys conducted in Saginaw Bay by Michigan Department of Natural Resources (M. Thomas, Michigan Department of Natural Resources, personal communication) were used to classify age-1 yellow perch in the cormorant diets. We recognize there was some overlap between lengths of age-1 yellow perch and those of age- 0 and age- 2 and that our analysis included a few fish from these surrounding age classes, but this still represented juvenile yellow perch and was sufficient for the intended analysis.

To address our third objective, total consumption of all fish and specifically yellow perch (all ages and age-1 only) for the two top predators in Saginaw Bay, cormorants and walleye, were estimated for May-September in 2013 and 2014. Total consumption by cormorants was estimated by applying yearly nest counts (1,863 nests (2013), 2,710 nests (2014); E. Dunton, USFWS, personal communication; L. Wires, University of Minnesota, personal communication) 
to a published cormorant bioenergetics model for cormorants in the upper Great Lakes (Seefelt and Gillingham, 2008). The adult consumption parameter was $0.542 \mathrm{~kg} / \mathrm{day}$ based on the recommendations in the review from Ridgway (2010) for the breeding season. The number of non-breeding and immature birds was not known in Saginaw Bay; therefore we used three different estimates for low (0.185 non-breeders/nest; Schultz et al. 2013), medium (0.609 nonbreeders/nest; Madenjian and Gabrey 1995), and high (1 non-breeders/nest) abundance of nonbreeders in the system. For walleye, the age-specific consumption and diet composition information came from Jovanovic (2013). The Jovanovic (2013) study was used for several reasons: 1) these walleye diet data were sampled on the same seasonal time frame as the cormorants (monthly April/May-September); 2) the sampling occurred after round goby Neogobius melanostomus was established in Saginaw Bay and alewife abundance severely declined in Lake Huron; and 3) the diet data were broken up into yellow perch age classes consumed, thereby allowing for specific age-1 yellow perch consumption comparisons between the two predators. The age-specific walleye abundance was from an updated statistical catch-atage model for Saginaw Bay (Fielder and Bence, 2014). We show consumption estimates for the mean estimated and \pm 2 SE walleye abundances for comparison (Fielder and Bence, 2014). The cormorant and walleye total fish and yellow perch-specific consumption estimates were compared for 2013 and 2014.

\section{Results}

A total of 303 cormorant stomachs were collected during 2013, with only one empty stomach (Table 1). From the 302 stomachs containing diet items, 9,554 diet items were identified and only 9 prey items were unidentifiable and not included in further analysis. Cormorants consumed 21 prey types and the number of prey items ranged from 1 to 168 in a single stomach. 
Round goby had the highest frequency of occurrence by number $(78.9 \%)$, followed by yellow perch (13.4\%), emerald shiner (4.5\%), walleye (1.0\%), gizzard shad Dorosoma cepedianum (0.7\%), freshwater drum Aplodinotus grunniens (0.4\%), pumpkinseed Lepomis gibbosus (0.2\%), logperch Percina caprodes (0.2\%), goldfish Carassius auratus (0.2\%), and trout-perch Percopsis omiscomaycus $(0.1 \%)$. The overall highest consumption of species by biomass (prey species comprising $\geq 1 \%$ ) were round goby $(41.0 \%)$, yellow perch $(20.6 \%)$, walleye $(11.7 \%)$, freshwater drum (11.5\%), gizzard shad (3.7\%), emerald shiner (3.5\%), white sucker Catostomus commersoni (1.7\%), pumpkinseed (1.65\%), and white perch Morone americanus $(1.3 \%)$.

In 2014, 388 cormorant stomachs were collected and 14 stomachs were empty (Table 1). There were 13,804 identified prey items in the 374 stomachs containing prey items; only 15 items were unidentifiable. Cormorants consumed 25 different prey types, and the number of prey items in a single stomach ranged from 1 to 157 . Round goby had the highest frequency by number (56.6\%), followed by emerald shiner (25.2\%), yellow perch (8.0\%), gizzard shad (4.2\%), spottail shiner Notropis hudsonius (1.8\%), freshwater drum (1.2\%), trout-perch $(0.7 \%)$, walleye (0.6\%), Cyprinidae (0.5\%), and logperch (0.3\%). The overall highest consumption by biomass were round goby $(42.1 \%)$, yellow perch $(14.1 \%)$, emerald shiner $(12.5 \%)$, walleye $(9.4 \%)$, freshwater drum (7.8\%), gizzard shad (3.0\%), white bass Morone chrysops (1.7\%), spottail shiner (1.5\%), pumpkinseed (1.3\%), goldfish (1.1\%), and channel catfish Ictalurus punctatus $(1.0 \%)$

Monthly cormorant consumption patterns varied by sample location and were generally more variable at Spoils Island compared to Little Charity Island (Table 2, Fig. 3). Round goby comprised $20.8-94.7 \%$ of the cormorant diet composition by weight at Little Charity Island and Spoils Island during most months sampled. Notropis spp. contributed more to the diet by weight in 2014 compared to 2013 at both locations. Yellow perch were a significant portion of the 
biomass consumed during April - early May and again during some summer months at both locations during the study period. Gizzard shad were consistently consumed in August at both locations, comprising $10.1-28.6 \%$ of the diet composition by biomass. Freshwater drum was $13.6-69.9 \%$ of the composition by biomass at Spoils Island during April and May during both years. Other species consumed were sporadically important in the diet of cormorants during 2013 and 2014 (Table 2). Diet composition as percent by number had similar composition patterns except smaller species (e.g., gizzard shad, Notropis spp., round goby) were a larger proportion of the diet composition and species taken at larger sizes (e.g., walleye, white sucker, Morone spp.) were less prominent (Fig. 3).

Estimated total lengths of yellow perch consumed ranged from 34 to $287 \mathrm{~mm}$, with more than $93 \%$ of yellow perch under $115 \mathrm{~mm}$ (Fig. 4). Estimated total lengths of round goby consumed ranged from 15 to $172 \mathrm{~mm}$ with $98 \%$ of round goby under $105 \mathrm{~mm}$ (Fig. 4).

Total fish consumption by the breeding colonies in Saginaw Bay during 2013 was estimated to be between $394,036-517,477 \mathrm{~kg}$ of fish, or $14-19 \%$ as much as the mean walleye consumption of prey in Saginaw Bay from May-September (Table 3). In 2014, cormorants in Saginaw Bay consumed 573,181 - 752,745 kg of fish, or $24-31 \%$ as much as the mean walleye consumption from May-September. Cormorants are estimated to have consumed between 82,354 - 108,153 kg and 42,358 - 55,628 kg of yellow perch (all ages) based on 2013 and 2014 diet compositions, respectively. Considering specifically age-1 yellow perch, cormorants consumed $13-17 \%$ and $8-11 \%$ as much as the mean walleye consumption in 2013 and 2014, respectively.

\section{Discussion}


Piscivorous waterbirds are top predators in aquatic systems and can affect fish communities in multiple ways, such as direct predation, potential competition, and through indirect pathways (Steinmetz et al., 2003; Wiese et al., 2008). Additional potential effects on recreational and commercial fishing opportunities have also been examined, especially as they relate to cormorants (VanDeValk et al., 2002; Östman et al., 2013). Because Saginaw Bay is a valuable recreational and commercial fishing location (Fielder et al., 2014), cormorants on Saginaw Bay have the potential to affect multiple pathways in the ecosystem. Cormorants from Little Charity Island and Spoils Island colonies consumed a variety of prey items, mostly nongame, soft-bodied fish species. Round goby and Notropis spp. were prevalent or dominant during most months sampled during the two breeding seasons. Prey items consumed reflect the fish community within Saginaw Bay (Fielder and Thomas, 2014), so we assumed most cormorant consumption occurred within the bay and not in the main basin of Lake Huron.

Cormorant consumption of sportfish was limited during 2013 and 2014 in Saginaw Bay. Sportfish were not the dominant diet item by number or biomass except in April 2013 when yellow perch (almost all age-1) were the dominant component (biomass and number) of the diet at Little Charity Island and in June 2013 when walleye comprised 54\% of the diet biomass at Spoils Island. Yellow perch consumption occurred mostly in April and early May, a pattern which has been found in other areas of the Great Lakes (Diana et al., 2006; Madura and Jones, 2016). However, in Saginaw Bay the consumption during early spring was not of spawning adults, but of age- 1 fish. Yellow perch consumed in the fall were mostly age- 0 fish. Consumption of juvenile fish by cormorants has been identified in other systems as a bottleneck prior to recruitment into a fishery (Lantry et al., 2002; Rudstam et al., 2004; Fielder, 2008), and it could be a factor for yellow perch in Saginaw Bay. However in some percid-dominated fish communities, cormorant diets do not reflect that dominance (Bur et al., 1997; Hundt et al., 2013; 
Ofukany et al., 2015) and have been found instead to depend on preferred, non-percid prey where available (DeBruyne et al., 2013). The large contribution of Notropis spp. and gizzard shad (during fall) in the Saginaw Bay cormorant diets is consistent with this, and the prevalence of round goby in the diet is similar to other areas in the Great Lakes (Somers et al., 2003; Coleman et al., 2012; Johnson et al., 2010, 2015a,b; Van Guilder and Seefelt, 2013; Madura and Jones, 2016).

The inclusion and dominance of round goby in the cormorant diets was not unexpected. Based on work done in areas of the Great Lakes, cormorants began exploiting round goby only 2-5 years after round goby became established in an area (Somers et al., 2003; Coleman et al., 2012; Johnson et al., 2010, 2015 a,b). Round goby have been collected in Saginaw Bay since 1999 and recorded in the diets of other piscivores in Saginaw Bay since 2000 (Fielder and Thomas, 2014), so it is likely that cormorants have been exploiting round goby in Saginaw Bay since the early 2000s. This coincides with the alewife population crash in Lake Huron (Roseman and Riley, 2009), so cormorants in Saginaw Bay may not have been substantially affected by the changing forage base. While it cannot be known for certain when round goby became the dominant diet item, our results show that it was the dominant diet item during the 2013 and 2014 breeding season in Saginaw Bay. The reliance of cormorants on soft-bodied forage fish that are available during most months in Saginaw Bay may infer that these prey are buffering impacts of predation on yellow perch.

Despite the predation by cormorant predation on yellow perch, and age-1 yellow perch in particular, the exact contribution of cormorants to the yellow perch mortality rate cannot be determined from these data. Nonetheless, comparing the consumption of yellow perch by cormorants to that of walleye (Table 3), we were able to quantify the effect of cormorant predation relative to the top predator in the bay. Based on the current information available for 
walleye and cormorants, we estimated that cormorants consume $8-17 \%$ as much age- 1 yellow perch as walleye from April to October. This comparison is valuable given walleye are well studied in Saginaw Bay and framing cormorant consumption in terms of walleye consumption brings these estimates into perspective. Even though cormorants consume a small fraction of yellow perch compared to walleye, this predation comes at life stages that are beyond traditional compensatory mechanisms (Rudstam et al., 2004) such that these mortality sources are likely additive. In 2016, walleye harvest regulations were adjusted to reduce predation pressure on yellow perch; management actions that limit cormorant consumption during early spring on Saginaw Bay would likely further reduce predation pressure on age-1 yellow perch. Obtaining updated abundances and seasonal diet information of other top predators in Saginaw Bay (e.g., smallmouth bass Micropterus dolomieu, white bass Morone chrysops) would help to establish their potential contribution to age-1 yellow perch mortality (Fetzer et al., 2016). Other possible contributors to the high yellow perch mortality could be over-winter mortality for the age- 0 yellow perch (Ivan et al., 2011; Fielder and Thomas, 2014). Future efforts to refine Saginaw Bay food web dynamics could benefit from incorporating abundance information of major prey species (e.g., yellow perch, round goby, Notropis spp.) and seasonal abundances of fish and avian top predators, such as cormorants, but also gulls, terns, and herons, which have been found to exert as much, and often higher, predation pressure on fish communities (Hostetter et al., 2015).

Future examinations of the effects of cormorant foraging on sportfish populations in Saginaw Bay would be improved by determining age-specific yellow perch abundances, as well as accurately accounting for the number of non-breeder and migrant cormorants. Given that yellow perch are mainly consumed in April when spring migrants are present, it is possible that the amount of predation estimated here (based on nest counts) is a conservative estimate. 
Understanding the magnitude and duration of cormorant migration on Saginaw Bay, and

subsequently cormorant predation (through continued diet monitoring), could influence potential cormorant management strategies in Saginaw Bay. Some locations in the Great Lakes region are not impacted by seasonal migrants (e.g., Leech Lake, MN) while others are heavily influenced by the seasonal influx of cormorants (e.g., Brevoort Lake, MI and Oneida Lake, NY), and this difference is reflected in their approach to cormorant management (Dorr et al., 2010; DeVault et al., 2012; Schultz et al., 2013). Changes in the forage fish community may affect cormorant consumption, therefore continued monitoring of cormorant diets would establish patterns of diet composition during years of fluctuating prey abundances (DeBruyne et al., 2012, 2013; Schultz et al., 2013). However, round goby may continue to be the dominant diet item regardless of other species' abundances as seen in other areas with long-term cormorant diet studies where round goby serve as a predation buffer for sportfish previously impacted by cormorant predation (Johnson et al., 2010, 2015a). If round goby continue to dominate cormorant diets, the impact of cormorant predation on the yellow perch population in Saginaw Bay may be reduced.

\section{Acknowledgements}

Funding for this study was provided by the Michigan Department of Natural Resources and the U.S. Geological Survey Great Lakes Science Center. We would like to thank D. Arsnoe, E. Krom, R. Liedke, D. Marks, A. Messing, J. Nave, and T. Wilson from U.S. Department of Agriculture Animal and Plant Health Inspection Services-Wildlife Services for collecting the cormorants; P. Thompson, R. Hunter, N. Stoynoff, D. Castle, J. Ross, R. Young, J. Sutherland, and D. Bowser from U.S. Geological Survey Great Lakes Science Center for assistance with processing the diet samples; M. Thomas from the Michigan Department of Natural Resources, 
Fisheries Division for providing Saginaw Bay fisheries data; and E. Dunton from the U.S. Fish and Wildlife Service, Shiawassee National Wildlife Refuge and L. Wires from University of Minnesota for Saginaw Bay cormorant nest counts. Use of any trade names does not imply endorsement by the U.S. Geological Survey, U.S. Department of Agriculture, or Michigan Department of Natural Resources.

\section{Literature Cited}

Barks, P.M., Doucette, J.L., Somers, C.M., 2010. Lack of angling-sized yellow perch in a Canadian Boreal Shield lake: potential influences of growth rate, diet and predation by double-crested cormorants. Trans. Am. Fish. Soc. 139, 1029-1040.

Beckman, W.C., 1948. The length-weight relationship, factors for conversions between standard and total lengths, and coefficients of condition for seven Michigan fishes. Trans. Am. Fish. Soc. 75, 237-256.

Bur, M.T., Tinnirello, S.L., Lovell, C.D., Tyson, J.T., 1997. Diet of the double-crested cormorant in western Lake Erie. In: Tobin, M.E. (Ed.), Symposium on double-crested cormorants: population status and management issues in the Midwest. U.S. Dept. of Agriculture Tech. Bull No. 1879, pp. 73-84.

Burnett, J.A.D., Ringler, N.H., Lantry, B.F., Johnson, J.H., 2002. Double-crested cormorant predation on yellow perch in the eastern basin of Lake Ontario. J. Great Lakes Res. 28, $202-211$.

Carlander, K.D., Smith, L.L., 1945. Some factors to consider in the choice between standard, fork, or total lengths in fishery investigations. Copeia 1945, 7-12. 
Coleman, J.T.H., 2009. Diving behavior, predator-prey dynamics, and management efficacy of double-crested cormorants in New York State. Doctoral dissertation. Cornell University, Ithaca, New York.

Coleman, J.T.H., Adams, C.M., Kandel, M., Richmond, M.E., 2012. Eating the invaders: the prevalence of the invasive round goby (Apollonia melanostomus) in the diet of doublecrested cormorants on the Niagara River. Waterbirds 35(Sp. 1), 103-113.

Craven, S.R., Lev, E., 1987. Double-crested cormorants in the Apostle Islands, Wisconsin, USA: population trends, food habits, and fishery depredations. Colon. Waterbirds 10, 64-71.

DeBruyne, R.L., DeVault, T.L., Duerr, A.E., Capen, D.E., Pogmore, F.E., Jackson, J.R., Rudstam, L.G., 2012. Spatial and temporal comparisons of double-crested cormorant diets following the establishment of alewife in Lake Champlain, USA. J. Great Lakes Res. 38(Supplement 1), 123-130.

DeBruyne, R.L., Coleman, J.T.H., Jackson, J.R., Rudstam, L.G., VanDeValk, A.J., 2013. Analysis of prey selection by double-crested cormorants: a 15-year diet study in Oneida Lake, New York. Trans. Am. Fish. Soc. 142, 430-446.

DeVault, T. L., R. B. Chipman, S. C. Barras, J. D. Taylor, C. P. Cranker III, E. M. Cranker, and J. F. Farquhar. 2012. Reducing impacts of double-crested cormorants to natural resources in central New York: a review of a collaborative research, management, and monitoring program. Waterbirds 35 (Sp. 1):50-55.

Diana, J. S., S. Maruca, and B. Low. 2006. Do increasing cormorant populations threaten sportfishes in the Great Lakes? A case study in Lake Huron. J. Great Lakes Res. 32:306320. 
Dorr, B.S., Moerke, A., Bur, M., Bassett, C., Aderman, T., Traynor, D., Singleton, R.D., Butchko, P.H., Taylor, J.D., 2010. Evaluation of harassment of migrating double-crested cormorants to limit depredation on selected sport fisheries in Michigan. J. Great Lakes Res. 36, 215-223.

Elliott, R.F., Peeters, P.J., Ebener, M.P., Rybicki, R.W., Schneeberger, P.J., Hess, R., Francis, J.T., Eck, G.W., Madenjian, C.P., 1996. Conduction diet studies of Lake Michigan piscivores: a protocol. U.S. Fish and Wildlife Service, Fishery Resources Office, Report 96-2, Green Bay, Wisconsin.

Fetzer, W.W., Farrell, C.J., Jackson, J.R., Rudstam, L.G., 2016. Year class variation drives interactions between warm water predators and yellow perch. Can. J. Fish. Aquat. Sci. $73,1-12$.

Fielder, D.G., 2008. Examination of factors contributing to the decline of the yellow perch population and fishery in Les Cheneaux Islands, Lake Huron, with emphasis on the role of double-crested cormorants. J. Great Lakes Res. 34, 506-523.

Fielder, D.G., Bence, J.R., 2014. Integration of auxiliary information in statistical catch-at-age (SCA) analysis of the Saginaw Bay stock of walleye in Lake Huron. N. Am. J. Fish. Manag. 34, 970-987.

Fielder, D.G., Thomas, M.V., 2006. Fish population dynamics of Saginaw Bay, Lake Huron 1998 - 2004. Michigan Department of Natural Resources, Fisheries Research Report. No. 2083. Ann Arbor.

Fielder, D.G., Thomas, M.V., 2014. Status and trends of the fish community of Saginaw Bay, Lake Huron 2005-2011. Michigan Department of Natural Resources, Fisheries Report 03. Lansing. 
Fielder, D.G., Kolb, T.L., Goniea, T.M., Wesander, D.L., Schrouder, K.S., 2014. Fisheries of Saginaw Bay, Lake Huron 1986-2010. Michigan Department of Natural Resources, Fisheries Report 02. Lansing.

Haas, R.C., Schaeffer, J.S., 1992. Predator-prey and competitive interactions among walleye, yellow perch, and other forage fishes in Saginaw Bay, Lake Huron. Michigan Department of Natural Resources, Fisheries Research Report 1984, Ann Arbor.

Hartman, K.J., Margraf, F.J., 1992. Effects of prey and predator abundances on prey consumption and growth of walleyes in western Lake Erie. Trans. Am. Fish. Soc. 121, 245-260.

Hostetter, N J., Evans, A.F., Cramer, B.M., Collis, K., Lyons, D.E., Roby, D.D., 2015. Quantifying avian predation on fish populations: Integrating predator-specific deposition probabilities in tag recovery studies. Trans. Am. Fish. Soc. 144, 410-422.

Ivan, L.N., Hook, T.O., Thomas, M.V., Fielder, D.G., 2011. Long-term and interannual dynamics of walleye and yellow perch in Saginaw Bay, Lake Huron. Trans. Am. Fish. Soc. $140,1078-1092$.

Johnson, T.B., Allen, M., Corkum, L.D., Lee, V.A., 2005. Comparison of methods needed to estimate population size of round gobies (Neogobius melanostomus) in western Lake Erie. J. Great Lakes Res. 31, 78-86.

Johnson, J.H., Ross, R.M., McCullough, R.D., Mathers, A., 2010. Diet shift of double-crested cormorants in eastern Lake Ontario associated with the expansion of the invasive round goby. J. Great Lakes Res. 36, 242-247.

Johnson, J.H., Farquhar, J.F., Klindt, R.M., Mazzocchi, I., Mathers, A., 2015a. From yellow perch to round goby: A review of double-crested cormorant diet and fish consumption at Three St. Lawrence River Colonies, 1999-2013. J. Great Lakes Res. 41, 259-265. 
Johnson, J.H., McCullough, R.D., Farquhar, J.F., Mazzocchi, I. 2015b. Little Galloo Island, Lake Ontario: Two decades of studies on the diet, fish consumption, and management of double-crested cormorants. J. Great Lakes Res. 41, 652-658.

Jovanovic, C.M., 2013. Impacts of a recovering walleye population on an altered forage fish community in Saginaw Bay, Lake Huron. M.S. Thesis. University of Michigan, Ann Arbor.

Knight, R.L., Margraf, F.J, Carline, R.F., 1984. Piscivory by walleyes and yellow perch in western Lake Erie. Trans. Am. Fish. Soc. 113, 677-693.

Lantry, B.F., Eckert, T.H., Schneider, C.P., Chrisman, J.R., 2002. The relationship between the abundance of smallmouth bass and double-crested cormorants in the eastern basin of Lake Ontario. J. Great Lakes Res. 28, 193-201.

Lewis, H.F., 1929. The natural history of the double-crested cormorant (Phalacrocorax auritus auritus (Lesson)). Ru-Mi-Lou Books, Ottawa.

Ludwig, J.P., Hull, C.N., Ludwig, M.E., Auman, H.J., 1989. Food habitats and feeding ecology of nesting double-crested cormorants in the upper Great Lakes, 1986-1989. Jack Pine Warbler 67, 115-126.

Madura, P.T., Jones H.P., 2016. Invasive species sustain double-crested cormorants in southern Lake Michigan. J. Great Lakes Res. 42, 413-420.

Neuman, J., Pearl, D.L., Ewins, P.J., Black, R., Weseloh, D.V., Pike, M., Karwowski, K., 1997. Spatial and temporal variation in the diet of double-crested cormorants (Phalacrocorax auritus) breeding on the lower Great Lakes in the early 1990s. Can. J. Fish. Aquat. Sci. $54,1569-1584$. 
Ofukany, A.F., Hobson, K.A., Wassenaar, L.I., Bond, A.L., 2015. Prey consumption and trace element concentrations in double-crested cormorants (Phalacrocorax auritus) from Lake Winnipeg, Canada. J. Great Lakes Res. 41, 643-651.

Östman, Ö., Boström, M.K., Bergström, U., Andersson, J., Lunneryd, S.G., 2013. Estimating competition between wildlife and humans-a case of cormorants and coastal fisheries in the Baltic Sea. PloS one, 8(12), p.e83763. doi:10.1371/journal.pone.0083763

Ridgway, M.S., 2010. A review of estimates of daily energy expenditure and food intake in cormorants (Phalacrocorax spp.). J. Great Lakes Res. 36, 93-99.

Ridgway, M.S., Fielder, D.G., 2012. Double-crested cormorants in the Laurentian Great Lakes: issues and ecosystems. Pages 733-764 in W. W. Taylor, A. J. Lynch, and N. J. Leonard, editors. Great Lakes fisheries policy and management: a binational perspective. 2 nd edition. Michigan State University Press, East Lansing, Michigan.

Ridgway, M.S., Dunlop, W.I., Lester, N.P., Middel, T.A., 2012. Relative demand by doublecrested cormorants and anglers for fish production from lakes on Manitoulin Island, Lake Huron. J. Great Lakes Res. 38, 514-523.

Riley, S.C., Roseman, E.F., Nichols, S.J., O'Brien, T.P., Kiley, C.S., Schaeffer, J.S., 2008. Deepwater demersal fish community collapse in Lake Huron. Trans. Am. Fish. Soc. 137, $1879-1890$.

Roseman, E.F., Riley, S.C., 2009. Biomass of deepwater demersal forage fishes in Lake Huron, 1994-2007: Implications for offshore predators. Aquat Ecosyst Health Manag. 12, 29-36.

Rudstam, L.G., VanDeValk, A.J, Adams, C.M., Coleman, J.T.H., Forney, J.L., Richmond, M.E., 2004. Cormorant predation and the population dynamics of walleye and yellow perch in Oneida Lake. Ecol. Appl. 14, 149-163. 
Salz, R.J., 1989. Factors influencing growth and survival of yellow perch from Saginaw Bay, Lake Huron. Michigan Department of Natural Resources, Fisheries Research Report 1964, Ann Arbor.

Schaeffer, J.S., Diana, J.S., Haas, R.C., 2000. Effects of long-term changes in the benthic community on yellow perch in Saginaw Bay, Lake Huron. J. Great Lakes Res. 26, 340351.

Schultz, D.W., Carlson, A.J., Mortensen, S., Pereira, D.L., 2013. Modeling population dynamics and fish consumption of a managed double-crested cormorant colony in Minnesota. N. Am. J. Fish. Manag. 33, 1283-1300.

Schneider, J.C., Laarman, P.W., Gowing, H., 2000. Length- weight relationships. p. 1-16. In J.C. Schneider [eds.], Manual of fisheries survey methods II: With periodic updates. Michigan Department of Natural Resources.

Seefelt, N.E., Gillingham, J.C., 2008. Bioenergetics and prey consumption of breeding doublecrested cormorants in the Beaver Archipelago, northern Lake Michigan. J. Great Lakes Res. 34, 122-133.

Somers, C.M., Lozer, M.N., Kjoss, V.A., Quinn, J.S., 2003. The invasive round goby (Neogobius melanostomus) in the diet of nestling double-crested cormorants (Phalacrocorax auritus) in Hamilton Harbour, Lake Ontario. J. Great Lakes Res. 29, 392-399.

Steinmetz, J., Kohler, S.L., Soluk, D.A., 2003. Birds are overlooked top predators in aquatic food webs. Ecology 84, 1324-1328.

Truemper, H.A., Lauer, T.E., 2005. Gape limitation and piscine prey size-selection by yellow perch in the extreme southern area of Lake Michigan, with emphasis on two exotic prey items. J. Fish Biol. 66, 135-149. 
Traynor, D., Moerke, A., Greil, R., 2010. Identification of Michigan fishes using cleithra. Great Lakes Fishery Commission, Special Publication 2010- 2, Ann Arbor, Michigan.

United States Fish and Wildlife Service (USFWS). 2003. Final environmental impact statement Doubled-crested cormorant management in the United States. Washington D.C. available at: http://www.fws.gov/migratorybirds/currentbirdissues/management/cormorant/Cormorant FEIS.pdf

VanDeValk, A.J., Adams, C.M., Rudstam, L.G., Forney, J.L., Brooking, T.E., Gerken, M.A., Young, B.P., Hooper, J.T., 2002. Comparison of angler and cormorant harvest of walleye and yellow perch in Oneida Lake, New York. Trans. Am. Fish. Soc. 131, 27-39.

Van Guilder, M.A., Seefelt, N.E., 2013. Double-crested cormorant (Phalacrocorax auritus) chick bioenergetics following round goby (Neogobius melanostomus) invasion and implementation of cormorant population control. J. Great Lakes Res. 39, 153-161.

Wiese, F.K., Parrish, J.K., Thompson, C.W., Maranto, C., 2008. Ecosystem-based management of predator-prey relationships: piscivorous birds and salmonids. Ecol. Appl. 18, 681-700.

Wires, L.R., Cuthbert, F.J., 2006. Historic populations of the double-crested cormorant (Phalacrocorax auritus): implications for conservation and management in the $21 \mathrm{st}$ century. Waterbirds 29, 9-37. 
Table 1. Number of cormorant stomachs (Samples) and total number of prey items (Prey) collected from Little Charity Island and Spoils Island during 2013 and 2014 by month.

\begin{tabular}{|c|c|c|c|c|c|}
\hline \multirow[b]{2}{*}{ Year } & \multirow[b]{2}{*}{ Month } & \multicolumn{2}{|c|}{ Little Charity Island } & \multicolumn{2}{|c|}{ Spoils Island } \\
\hline & & Samples & Prey & Samples & Prey \\
\hline \multirow{7}{*}{2013} & April & 30 & 747 & 26 & 316 \\
\hline & May & 25 & 1161 & 7 & 60 \\
\hline & June & 27 & 2150 & 18 & 315 \\
\hline & July & 26 & 1419 & 24 & 673 \\
\hline & August & 25 & 596 & 45 & 1320 \\
\hline & September & 26 & 456 & 24 & 350 \\
\hline & 2013 Total & 159 & 6529 & 144 & 3034 \\
\hline \multirow{9}{*}{2014} & early May & 25 & 705 & 20 & 403 \\
\hline & May & 28 & 1084 & 30 & 920 \\
\hline & June & 27 & 1210 & 44 & 1064 \\
\hline & July & 31 & 1517 & 31 & 974 \\
\hline & early August & 25 & 1859 & - & - \\
\hline & August & - & - & 58 & 1047 \\
\hline & late August & 26 & 1298 & - & - \\
\hline & September & 26 & 1273 & 17 & 465 \\
\hline & 2014 Total & 188 & 8946 & 200 & 4873 \\
\hline
\end{tabular}


Table 2. Cormorant diet composition by weight (\%) for the 10 species comprising largest overall diet weight from Saginaw Bay, Lake Huron, including all identifiable diet items from all collected samples in 2013 and 2014. Sample sizes and number of identified prey are described in Table 1. LCI = Little Charity Island; SPI = Spoils Island; NOT = Notropis spp.; FWD = Freshwater Drum; GIS = Gizzard shad; LEP = Lepomis spp.; ROG = Round Goby; WAE = Walleye; MOR = Morone spp.; WHS = White Sucker; YEP = Yellow Perch. 'Other' species include: black bullhead Ameiurus melas, black crappie Pomoxis nigromaculatus, bowfin Amia calva, brown bullhead Ameiurus nebulosus, bullhead Ameiurus spp., channel catfish, goldfish, logperch, longnose gar Lepisosteus osseus, quillback Carpiodes cyprinus, rockbass Ambloplites rupestris, and trout-perch.

\begin{tabular}{|c|c|c|c|c|c|c|c|c|c|c|c|c|}
\hline \multirow[b]{2}{*}{ Year } & \multirow[b]{2}{*}{ Site } & \multirow[b]{2}{*}{ Month } & \multicolumn{10}{|c|}{ Species } \\
\hline & & & NOT & FWD & GIS & LEP & ROG & WAE & MOR & WHS & YEP & Other* \\
\hline \multirow[t]{7}{*}{2013} & LCI & April & 2.0 & 3.4 & 2.9 & 9.6 & 0.3 & 0.0 & 0.0 & 1.3 & 74.2 & 6.6 \\
\hline & & May & 7.2 & 2.2 & 0.0 & 0.3 & 53.2 & 25.8 & 0.0 & 0.0 & 9.3 & 2.1 \\
\hline & & June & 0.6 & 0.0 & 0.0 & 0.0 & 94.1 & 0.0 & 0.0 & 0.0 & 4.6 & 0.8 \\
\hline & & July & 0.2 & 0.0 & 0.0 & 0.0 & 94.7 & 0.2 & 0.0 & 0.0 & 3.7 & 1.2 \\
\hline & & August & 5.9 & 17.6 & 0.0 & 0.0 & 25.5 & 3.7 & 8.5 & 7.7 & 30.9 & 0.1 \\
\hline & & September & 1.3 & 9.5 & 10.1 & 0.0 & 27.3 & 29.6 & 0.0 & 13.2 & 8.4 & 0.5 \\
\hline & SPI & April & 6.5 & 69.9 & 0.0 & 0.0 & 1.0 & 7.3 & 0.0 & 0.0 & 15.37 & 0.0 \\
\hline
\end{tabular}




$\begin{array}{ccccccccccc}\text { May } & 3.7 & 16.4 & 0.0 & 0.0 & 13.0 & 0.0 & 54.8 & 0.0 & 7.5 & 4.6 \\ \text { June } & 12.6 & 6.6 & 0.0 & 0.0 & 6.0 & 55.2 & 0.0 & 0.0 & 13.4 & 6.2 \\ \text { July } & 0.2 & 5.4 & 7.9 & 0.0 & 77.4 & 2.0 & 0.3 & 0.0 & 6.1 & 0.8 \\ \text { August } & 2.2 & 1.0 & 11.9 & 0.0 & 64.8 & 9.1 & 0.0 & 0.0 & 5.7 & 5.2 \\ \text { September } & 0.0 & 12.5 & 19.5 & 0.0 & 63.8 & 1.7 & 1.9 & 0.0 & 0.5 & 0.2\end{array}$

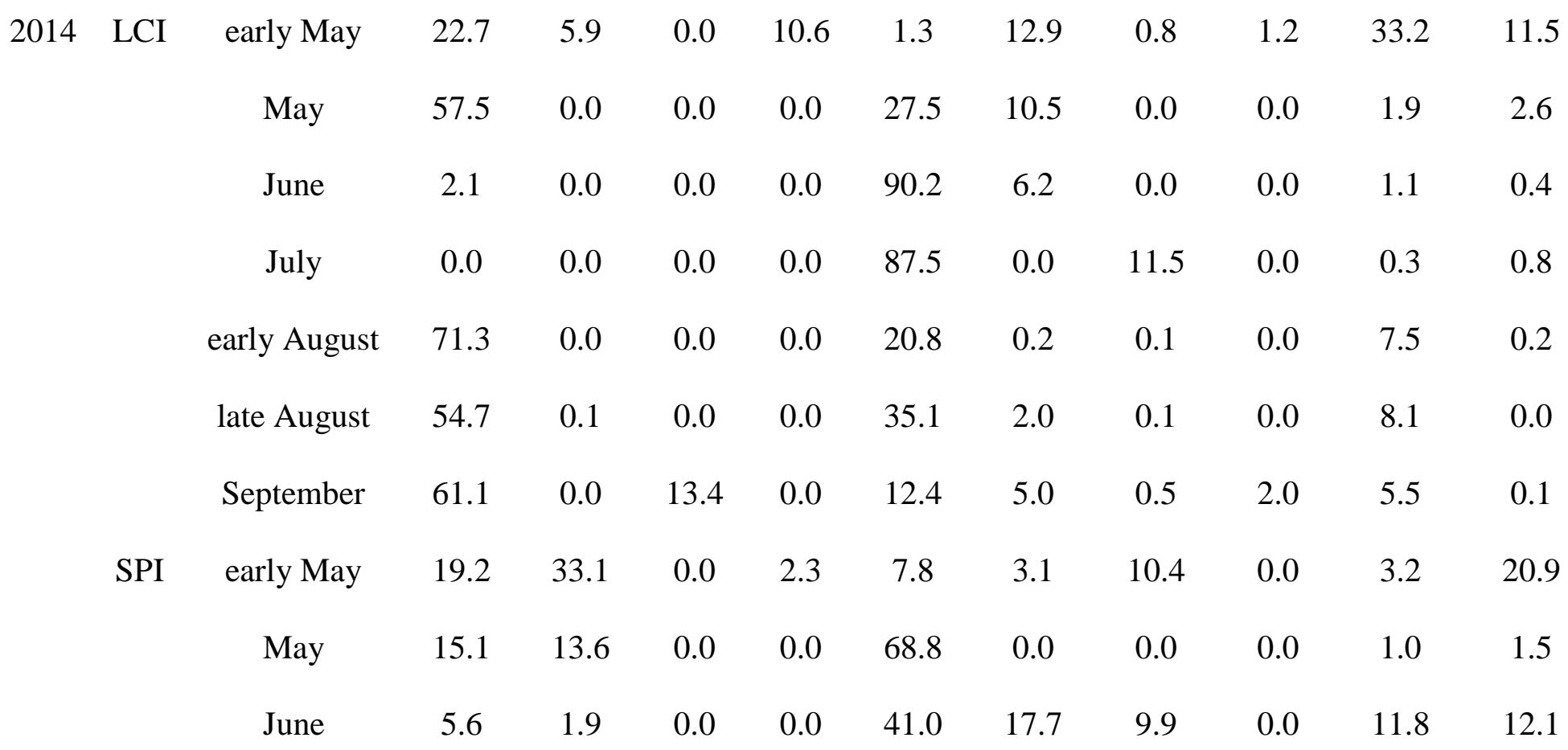




\begin{tabular}{ccccccccccc} 
July & 22.7 & 0.0 & 0.0 & 0.0 & 42.8 & 30.1 & 0.1 & 0.1 & 4.1 & 0.2 \\
August & 0.6 & 2.7 & 2.9 & 0.0 & 77.8 & 0.3 & 0.1 & 0.0 & 2.7 & 12.9 \\
September & 0.0 & 0.0 & 28.6 & 0.0 & 60.1 & 0.3 & 0.0 & 0.0 & 0.0 & 11.0 \\
\hline
\end{tabular}


Table 3. Estimated walleye and cormorant total consumption (kilograms) in Saginaw Bay during 2013 and 2014. Mean walleye total consumption (with 95\% CI) combined updated abundance estimates from statistical catch-at-age models (Fielder and Bence 2014) and consumption and diet estimates from Jovanovic (2013). Cormorant total fish consumption was based on the nest counts during 2013 and 2014 and consumption was based on diet composition determined in this study. See Methods for explanation of cormorant low, medium, and high non-breeder abundance. Percent in parentheses is the cormorant consumption compared to that of walleye (mean consumption) and walleye abundance $95 \%$ CI range below.

\begin{tabular}{|c|c|c|c|c|c|}
\hline \multirow[b]{2}{*}{ Year } & & \multirow[b]{2}{*}{ Walleye } & \multicolumn{3}{|c|}{ Cormorant } \\
\hline & & & Low & Medium & High \\
\hline \multirow[t]{6}{*}{2013} & Total Fish & $2,785,478$ & $394,036(14 \%)$ & $458,256(16 \%)$ & $517,477(19 \%)$ \\
\hline & & $(2,163,616-3,407,344)$ & $12-18 \%$ & $13-21 \%$ & $15-24 \%$ \\
\hline & Total YEP & 701,940 & $82,354(12 \%)$ & $95,776(14 \%)$ & $108,153(15 \%)$ \\
\hline & & $(545,231-858,651)$ & $10-15 \%$ & $11-18 \%$ & $13-20 \%$ \\
\hline & Age-1 YEP & 306,403 & $39,601(13 \%)$ & $46,055(15 \%)$ & $52,006(17 \%)$ \\
\hline & & $(237,998-374,808)$ & $11-17 \%$ & $12-19 \%$ & $14-22 \%$ \\
\hline \multirow[t]{2}{*}{2014} & Total Fish & $2,421,141$ & $573,181(24 \%)$ & $666,598(28 \%)$ & $752,745(31 \%)$ \\
\hline & & $(1,797,280-3,045,009)$ & $19-32 \%$ & $22-37 \%$ & $25-42 \%$ \\
\hline
\end{tabular}


Total YEP

$$
610,128
$$

$(452,915-767,342)$

Age-1 YEP
266,326

$(197,701-334,951)$
$42,358(7 \%)$

$$
6-9 \%
$$

$22,182(8 \%)$

$7-11 \%$
49,262 (8\%)

$55,628(9 \%)$

$$
6-11 \%
$$$$
7-12 \%
$$

25,797 (10\%)

$29,131(11 \%)$

$8-13 \%$

$9-15 \%$ 


\section{Figure Captions}

Figure 1. Map of Saginaw Bay identifying locations where cormorant colonies were located; Spoils Island and Little Charity Island.

Figure 2. Yellow perch mean trawl catch-per-effort (CPE) of age-0 (bars) and age-1+ (line) from 1970-2013 during annual fall surveys in Saginaw Bay, Lake Huron (from Fielder and Thomas, 2014). $2003=2,451$ age- $1+$ yellow perch $/ 10$ minute tow.

Figure 3. Cormorant diet composition by number for identifiable items from Little Charity Island (top) and Spoils Island (bottom) in 2013 and 2014. See Table 1 for the number of prey items per month (n) and Table 2 for 'Other' species.

Figure 4. Total length frequency of occurrence distribution of round goby (left panel) and yellow perch (right panel) consumed by cormorants from Little Charity Island and Spoils Island during all months in Saginaw Bay during 2013 (top) and 2014 (bottom). Note the yaxis scales are different among graphs. 


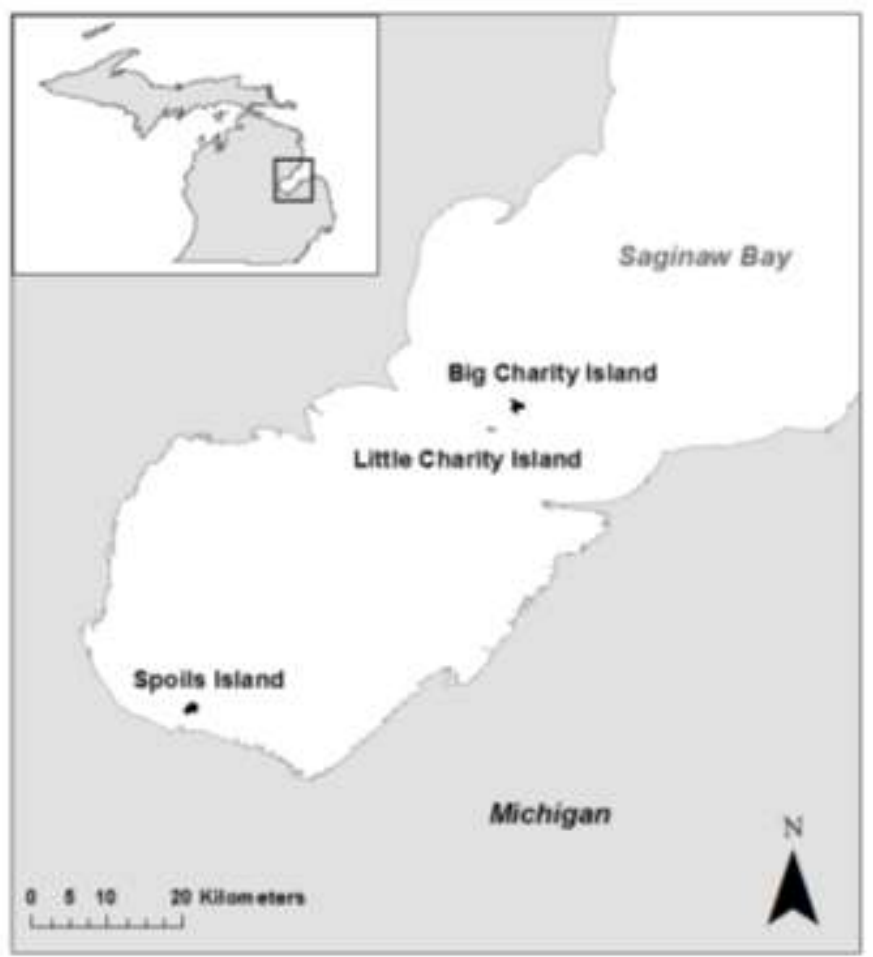

Figure 1. 


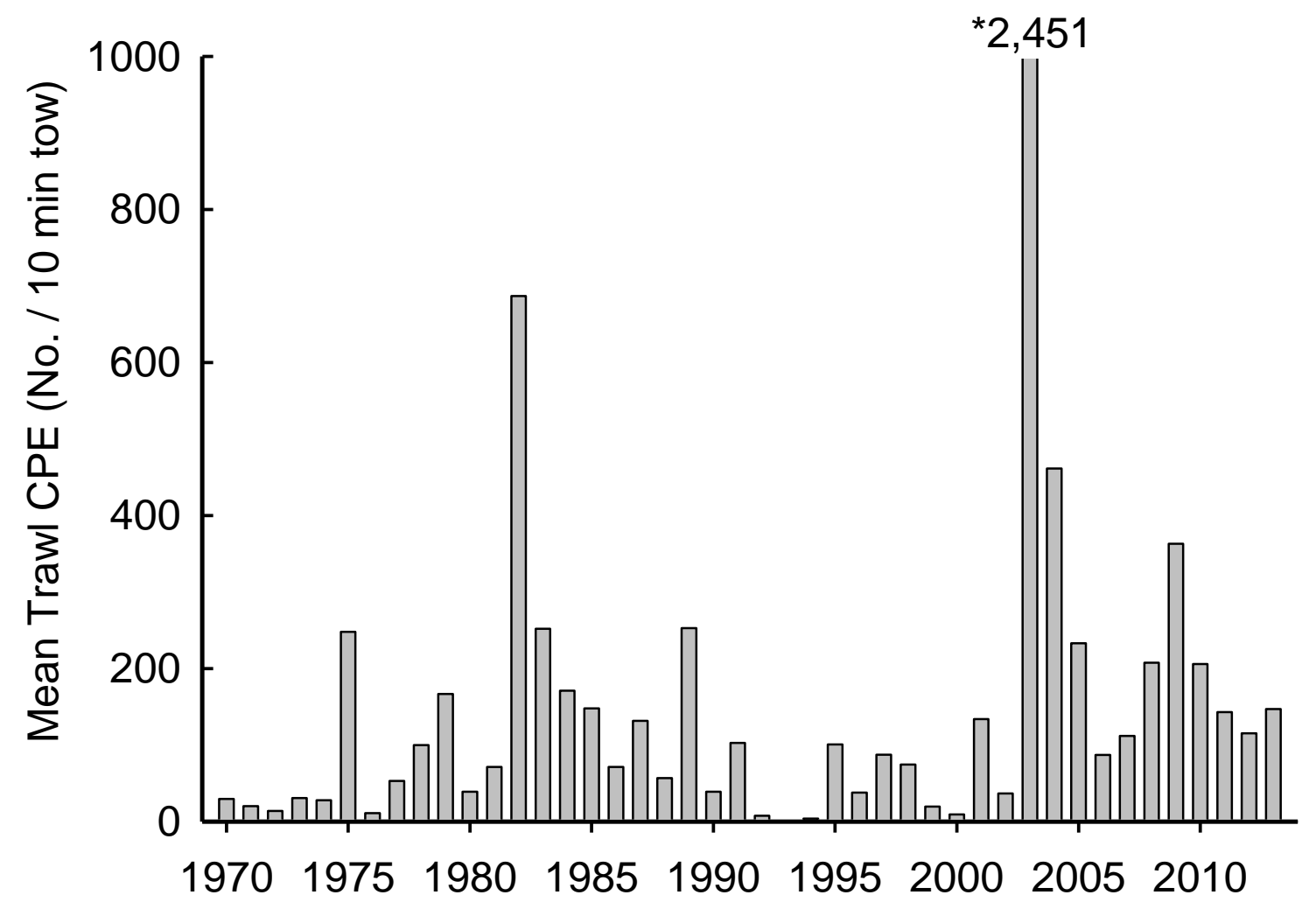

Figure 2 

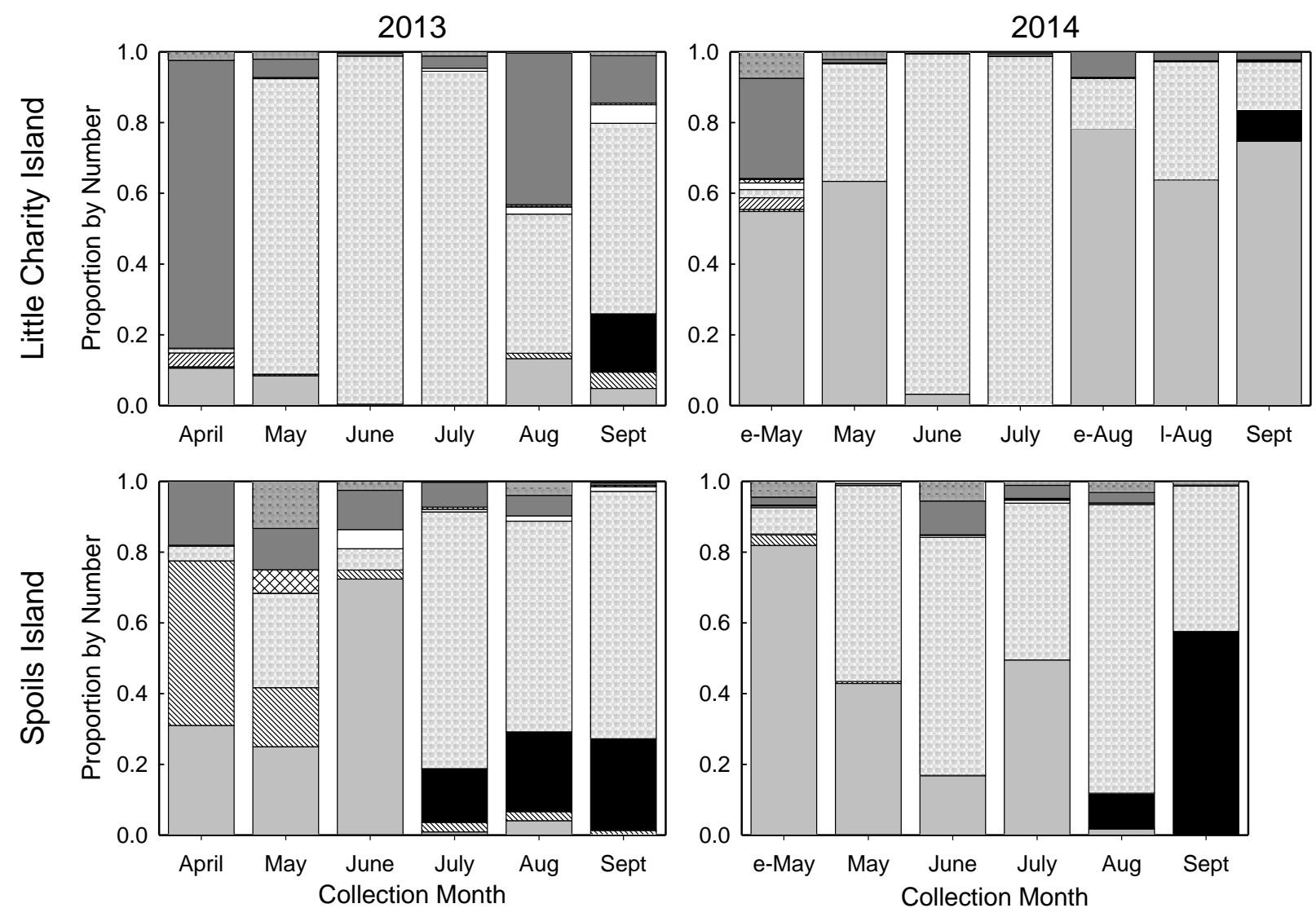

Notropis Freshwater Drum

Walleye $\$ 8 s 8$ Morone

White Sucker $\quad$ Yellow Perch Other

Figure 3. 

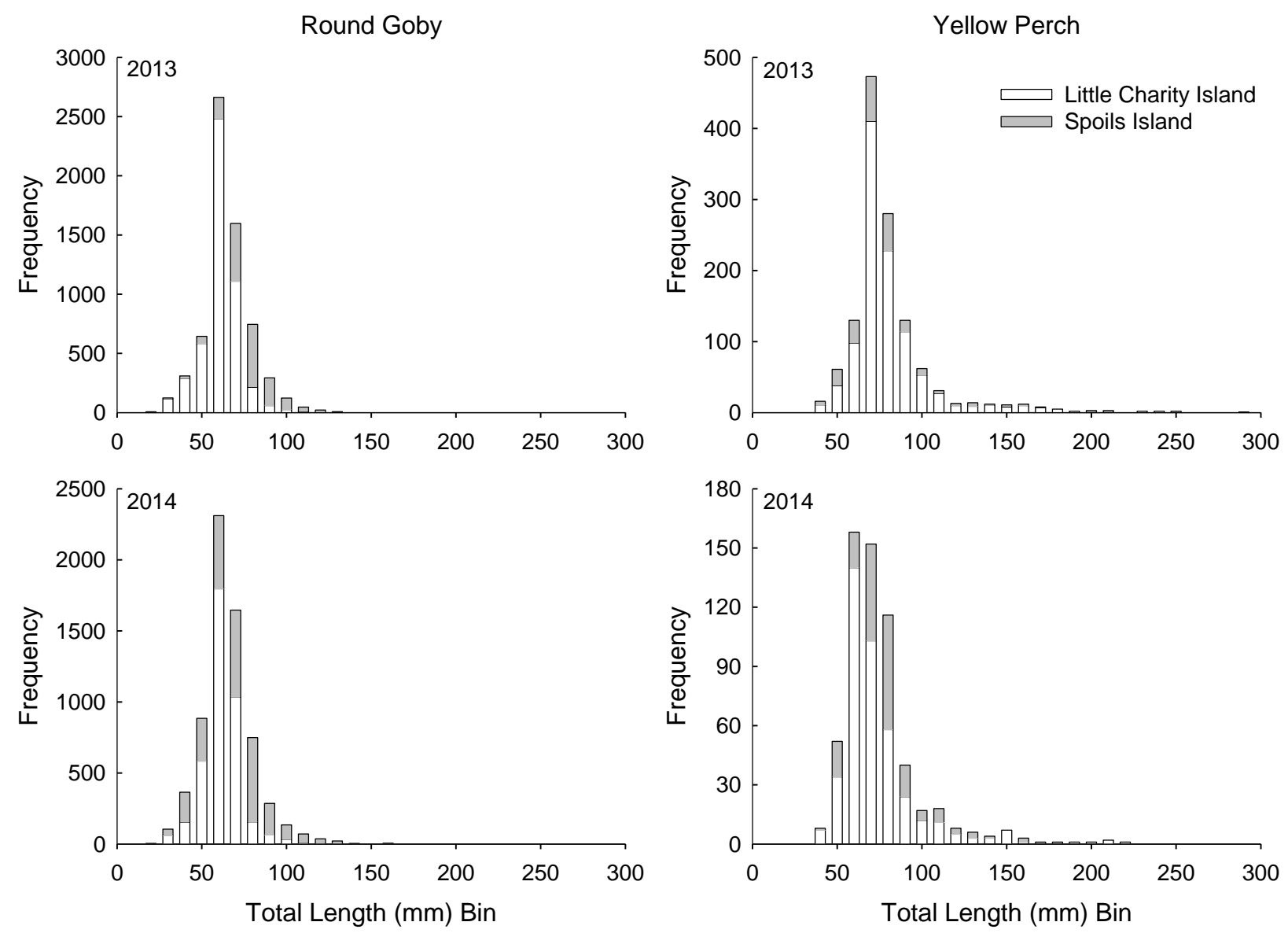

Figure 4. 